\title{
SYSTEM OF DAY SURGERY IN SLOVAKIA: ANALYSIS OF PEDIATRIC DAY SURGERY DISCREPANCIES IN THE REGIONS AND THEIR IMPORTANCE IN STRATEGY OF ITS DEVELOPMENT
}

\section{Beata Gavurova, Marek Soltes}

\section{Introduction}

In the beginning of the 20th century, the view on the organization of postoperative care was based on several obsolete assumptions concerning the surgical wound healing, the need for postoperative diet restrictions, as well as the limited mobilization of the patients. Nowadays, surgical care is rapidly shifting from in-hospital patient care towards outpatient concept. The process is based upon advancements in anesthesiological and surgical care and improved patient education and compliance that allow providing highly effective treatment with fewer hospital visits (Kurtinová, 2015; Škerjanc \& Fikfak, 2015). Thanks to this progress, and in order to utilize the reduced number of hospital beds more effectively, day surgery became more and more implemented even for more complex patient subgroups, such as elderly and pediatric population (Toftgaard \& Parmentier, 2006). In Slovakia, healthcare nonavailability represents a great barrier of day surgery development relating to senior citizens, socially vulnerable groups, segregated and marginalized communities with a weak primary healthcare system (Rusnáková \& Rochovská, 2014; Rusnáková, 2011).

At present, day surgery is increasingly considered possible golden standard for selected procedures that is advantageous not only for the patient himself, but also for the healthcare providers and the whole healthcare system. Day or outpatient surgery is defined as surgery or procedure that allows both admitting and discharging the patient on the same day. Overnight stay in the hospital within 23 hours' time span is termed extended recovery scheme.
The concept of short hospital stay is used in surgery that requires admission longer than 23 hours but shorter than 72 hours (International Association for Ambulatory Surgery - IAAS, international terminology, 2003). Despite the efforts to unify IAAS international terminology to facilitate the comparison of surgical data among the countries, significant differences still exist.

The development of high quality day surgery concept is a priority for the governments in the field of healthcare in many European countries. A recent survey conducted in 19 countries pointed out significant differences in the percentage of surgical procedures performed on the day surgery basis (Toftgaard \& Parmentier, 2006). The range is from less than $10 \%$ (Poland), to the extent of more than $80 \%$ (USA, Canada). These differences are evident not only among the countries but also on the national level - among different hospitals, theirs departments, as well as among different specialists within the same hospital. Determining factors of the above mentioned disparities may include the existence of different rules and incentives in different countries, variable reimbursement schemes and natural resistance of healthcare staff to implement the new concept of day surgery (Ivlev, Barták \& Kneppo, 2014).

\section{International Evidence on the Development of Day Surgery}

Day surgery is performed mainly in independent, integrated units of hospitals, eligible for day surgery performance. In different countries the situation may be different depending on the financial resources allocated (Maresova et al., 
2015; Mohelska et al., 2015; Szczygieł et al., 2014; Zavadil et al., 2015; Škampová et al., 2014). In some cases, extended recovery units are utilized (Smith et al., 2006), depending on the type of surgery carried out, the need for familiarity with a place of day surgery, or due to different social reasons (Šimrová et al., 2014). Such one-day in-hospital stay is more expensive and therefore, more typical for larger units of healthcare (e.g. Jarrett \& Roberts, 2006; Smith et al., 2012).

The diversity of healthcare systems in different countries also influences the trends in the number of elective day surgeries which vary considerably. Canada provides up to $65-70 \%$ of all operations as day-surgical procedures (e.g. Cullen et al., 2009; Chung et al., 2009), while Sweden 43\% (Maresova et al., 2015), Germany $70-80 \%$ (Hudecová, 2014) and USA 90\% (Hudecová, 2014).

IAAS (2003) collects data on the global scope of day surgery in order to implement benchmarking, enabling the specification of appropriate procedures for day surgery since 1994. When interpreting the benchmarking data, it is necessary to take into account significant differences in the healthcare systems of individual countries, differences in terminology used, different reporting of medical records, etc. (Toftgaard \& Parmentier, 2006).

\subsection{Research Studies Concerning Day- Surgery Performance in the World}

Only a few randomized trials deal with the selection of appropriate patients for day surgery procedures. As reported by the American Society of Anesthesiologists (ASA), physical condition is very important in the process of postoperative evaluation of the results, while the age and weight of the patient play an important role, too (e.g. Smith et al., 2006). As reported by some research studies (e.g. Aldwinckle \& Montgomery, 2004; Sinha et al., 2007), higher age of the patients is not a major obstacle in the uncomplicated course of day surgery but severe obesity is (measured by BMI) (Aldwinckle \& Montgomery, 2004; Sinha et al., 2007).

Numerous foreign studies declare extensive research activities in the field of day surgery and show its considerable benefits, especially from the procedural point of view. The major limitation of the available data is the specificity of the research problem that makes it difficult to compare. Analyzes aimed at addressing the needs of day surgery for pediatric population are lacking even more. The most probable reason is very specific nature of this kind of outpatient surgery.

The development of day surgery is partly attributable to the need to reduce the number of hospital beds and thus to save some resources. Nevertheless, there are very few clinical studies comparing the results of traditional in-hospital surgery and day surgery procedures (Castoro et al., 2007). Those that were carried out failed to show any significant differences in the results (e.g. Castells et al., 2001; Corvera et al., 1996; Fedorowicz, 2005; Hollington et al., 1999). As a result, in conclusion, only safety of performing day surgery may be highlighted, provided all recommended instructions and organizational principles are met and respected (Jarrett \& Roberts, 2006; Smith et al., 2006).

Day surgery must be linked with sociomedical services, due to transfer of preoperative and postoperative care into outpatient environment. In countries with well-developed systems of primary health care, general practitioners play a key role in the day surgery system because they directly assess whether the patient is suitable for day surgery or not. These considerations are particularly important in pediatric population as these patients are fully dependent on their relatives or carers.

\section{Medical Results}

Numerous studies declare positive medical results associated with the implementation of day surgery procedures. The incidence of death and major morbidity directly associated with day surgery is extremely low (<1\%) (Lemos \& Regalado, 2006; Schnaider and Chung, 2006). Day surgery related admissions to hospital within 30 days vary in the range from $0.28 \%$ to $1.5 \%$ (Coley et al. 2002; Mezei \& Chung, 1999; Twersky \& Philip, 2008). The frequency of enforced admissions can be reduced by implementing appropriate clinical practice in day surgery (clinical pathways). Calland et al. (2001) confirmed in their study that their introduction has increased the number of discharged patients on the same day from $21 \%$ to $72 \%$ and reduced unplanned postoperative patient hospitalizations.

\section{Social Results}

A high level of patient satisfaction with day surgery is declared by the results of numerous 
studies (e.g. Fan et al., 1997; Hicklin et al., 1999; Hunt et al., 1999; Lau et al., 2000). Patients' satisfaction is affected by the following aspects: continuous postoperative pain control (McHugh \& Thoms, 2002), a short waiting period before surgery, the friendly behavior of the staff, phone check of the health status following after surgery.

\section{Financial Results of Day Surgery}

Financial results of day surgery versus inpatient surgery (taking into account the application of the same surgical procedures) are relatively well quantified and are on average $25 \%-68 \%$ lower (Castoro et al. 2007).

\subsection{Overnight Healthcare in Slovakia}

Overnight healthcare in Slovakia is available only for the last ten years (the term is used complementary to the concept of day surgery). Overnight healthcare is successfully implemented in several countries with considerable trend towards increasing its share on the overall number of surgeries. The introduction of the concept in Slovakia is fairly slow. Only $7 \%$ of the surgical procedures are performed within the model of overnight healthcare. The development of overnight healthcare in Slovakia is closely associated with the foundation of the Slovak Association of Day Surgery (SADS).

\section{Main tasks of SADS:}

- to work as a multidisciplinary forum for the exchange of knowledge and experience from different surgical specialties in day surgery,

- to contribute to the creation and expansion of high-quality day surgery,

- to participate in the promotion of day surgery in Slovakia,

- to participate in educational projects to promote day surgery,

- to participate in the preparation of legislative conditions for the existence of day surgery,

- to organize scientific seminars focusing on day surgery.

An important milestone in the development of day surgery in Slovakia in 2002 was the release of pricing measures of the Ministry of Finance permitting payment for seven procedures in ophthalmic day surgery (Vidová, 2012). In 2003, the reported price measures already contained 174 types of day surgery. In 2014, SADS pushed through a legislative framework for the establishment of day surgery providers as well as the decree of the Ministry of Health bringing a list of about 230 operations suitable for day procedures. This number encounters for about $30 \%$ of all types of surgeries provided in Slovakia. As reported by (Vidová, 2014), some of the reasons blocking further expansion of day surgery in Slovakia include geographical conditions and social situation. After a day surgery procedure patient must undergo several health checks in the upcoming days, which is a problem particularly for elderly people in remote villages (e.g. some cities bus services run only sporadically). Partial solution might be the pressure from the insurance companies, especially on smaller hospitals, to shorten the hospitalization periods. In 2009, SADS made a proposal that the providers do not get paid for the admission of the patient (current system) but for a specific procedure performed. Additional payment would also be offered in case that the in-hospital period would be shortened to $2-3$ days.

In 2007, the Health Care Surveillance Authority (HCSA) declared 37,000 services provided through the overnight healthcare which was about $45 \%$ more than in 2006 (HCSA, Michalič, 2014). In fact, day surgery cases are the most common procedures performed in most hospitals. In 2007, the insurance companies paid from the public sources about $9,560,000$ Eur for day surgery. It was estimated that hospitals received direct payments of 896 million Eur. Further development of day surgery could decrease overall healthcare costs (Vidová, 2014) by reducing the costs of the hospital bed departments. According to the Ministry of Health analysis, there were more beds in hospitals in Slovakia than necessary, so their reduction should be achievable.

Despite the enormous efforts of the SADS, day surgery in Slovakia failed to develop up to its potential (Vidová, 2014). According to SADS, the ideal medical fields for day surgery implementation are ophthalmology, otorhinolaryngology and gynecology. Also general surgeons, orthopedics and plastic surgeons could operate more through day surgery model.

Regarding the reimbursement of procedures by the insurance companies, there is huge dissatisfaction among hospitals with the 
reimbursement policy, as well as reimbursement payments for terminated hospitalization. E.g. some teaching hospitals receive $50 \%$ to $100 \%$ higher payment for the same procedure; between some hospital departments there may be a difference up to $40-50 \%$. Since August 2011 it is compulsory to publish the contracts on the web portals, which allows cross-price comparison of reimbursement for the given providers (Eckhardtová, 2014).

Another interesting landmark in the development of day surgery was related to the economy of state owned health insurance company. Very strict management regime had to be adopted due to its operating loss in amount of 70 million Eur. This was one of the reasons for the preparation and implementation of the system of health care "services separately paid" which also include the day surgery cases. This model includes all hospitalizations lasting within 96 hours, where the prices were lowered by $30-50 \%$ compared to prices for regular finished hospitalizations. The state health insurance company offered new contracts to some hospitals, where the contracted volumes of the care were cut down despite the fact that the number of provided procedures was even higher than the original contract quota. Despite higher real costs of the care provided, the state health insurance company continued in lowering the payments. In 2011, private insurance company Dôvera terminated the contracts with many hospitals, offering the new ones anticipated more disadvantageous for the providers. For these reasons, Slovak hospitals appealed to define realistic payments for the procedures performed and reduce unjustified differences in payments. Nevertheless, the state owned insurance company refused to negotiate both the prices offered and the length of 96 hours admission reimbursed only as the overnight care which obviously could not be considered an acceptable offer for the hospitals (Eckhardtová, 2014).

The year 2009 was important for the development of pediatric day surgery as new conditions were effectively introduced. The list of possible day surgery procedures was broadened to 450 operations in different surgical fields, of which about 130 procedures included the pediatric population (Hudecová, 2014). Many pediatric surgeons shared the decision of the Ministry of Health to promote day care, even though the conditions required for pediatric day surgery are much more complex compared to adult population. Slovak medical experts on day surgery draw attention to the lack of availability of pediatric day surgery which is limited due to limited contracts offered by the health insurance companies as well as financial limitations. If the health care provider is not offered a fair contract, the majority of surgeons would recommend hospitalization care as it does not seem ethical to make the patient pay for the services which are otherwise available free of charge. As reported by Babala (2014) - a specialist in pediatric day surgery pediatric day surgery is not a luxury, the real luxury is to operate the patient in the hospital, where the insurance company pays for the same operation twice as much or even more.

Basic regulations for pediatric day surgery in Slovakia include:

- procedure must not be longer than 90 minutes,

- operation must not cause excessive bleeding and/or significantly disrupt the abdominal or thoracic cavity,

- before the surgery, pediatric patient must be in a good health and any possible systemic disease must be compensated,

- day surgery can only be provided on the elective basis, it is not applicable for acute and urgent cases,

- day surgery for children is prohibited by legislation in following situations: child suffers from failing liver or heart, has a bleeding disorder, new onset heart murmur, cancer, uncontrolled diabetes mellitus, infectious disease, or severe bronchial asthma,

- specific post-surgical complications must be considered preoperatively in those children, who were born prematurely, with low birth weight and/or with diagnoses that may result in respiratory arrest after the surgery,

- day surgery must not be provided to pediatric patients, whose parents cannot take care of them during the first hours after the release,

- each patient must be healthy 14 days prior to surgery under general anesthesia, must not have any limiting chronic diseases and must have a secure access to the hospital within $50 \mathrm{~km}$ distance. If the criterion of secure access is not met, the procedure can also be performed with the requirement of overnight stay the hospital. 
Achieving optimal results and ensuring maximum safety during the surgical care are primary endpoints for any surgeon. Therefore, pediatric surgeons have to consider very carefully and consistently, all health and social risks prior to the indication of day surgery under general anesthesia on the individual basis (regardless of organizational and financial aspects of the healthcare system).

Restrictions applied on the execution of pediatric day surgery that were already mentioned enforce even greater personal responsibility for pediatric surgeons because the surgeon is the one who diagnose, indicates surgery, operates the patient and is hold responsible for the result and possible negative consequences of the decisions made. Day surgery is very demanding and there is no training ground for novice surgeons. Flawless result in pediatric surgery is a sign of high professionalism of the surgical team, as well as the proof of the skills and experience of anesthesiologists (Babala, 2014).

Despite legislative support for day surgery by the Ministry of Health, its development it is not progressive. Low rate of the day surgery procedures performed both in pediatric and adult population indicates presence of the systemic failures in the Slovak health care system influence by the strategy of the Ministry of Health, pricing policies of health insurance companies (state + private) and attitude of the health care providers (civil + private). Until 2013 there were no research studies available in Slovakia that were focused on any aspect of the development of day surgery, neither in pediatric, nor in the adult population. Based on the results of recent studies (Gavurová \& Hyránek, 2013; Gavurová et al., 2013; Šoltés, V. \& Gavurová, 2014a,b; Šoltés, M. \& Gavurová, 2014) several critical areas for development of day surgery in pediatric patients were identified, as presented in Table 1.

In relation to the presented facts, there is an absence of research studies describing the availability of pediatric day surgery in Slovakia - both technically and geographically. Furthermore, no information is available about the causal-consequential linkages between performance of pediatric day surgery and the complications, patient satisfaction, the need for subsequent health care, etc. Such data would be significant in the process of quantifying risk determinants for day surgery procedures. In many important foreign studies causal links with biosocial patient characteristics, comorbidities and type of provider (private clinics, specialized departments of large hospitals, etc.) were suggested (e.g. Aldwinckle \& Montgomery, 2004; Chung et al., 2009; Fleisher et al., 2004; Cullen et al., 2009 and others).

In Slovakia, data on the performed day surgery procedures are recorded exclusively by the National Health Information Centre since 2009. The structure of the data collected is determined by the Professional Guideline of the Ministry of Health about the overnight healthcare - Annual statement J (Ministry of Health) (Table 2). In addition to private clinics, day surgery is undertaken also in public hospitals, some of which re-profiled their surgical facilities for the needs of day surgery due to the running process hospital bed capacity reduction implemented via the Ministry of Health. To date 2005-12-31, the total amount of 37,131 beds in 73 general hospitals, 51 specialized hospitals, 16 sanatoriums, 6 hospices and 1 nursing home were registered. After the careful analysis, the Ministry of Health declared the need to reduce this number by 6,000 beds. The hospital network restructuring plan was based on the need of balanced regional deployment of hospital beds in individual specialties and regions, reaching an average utilization at the level of $80 \%$ in internist and $75 \%$ in surgical disciplines with the goal to shorten the length of hospital stay and overall number of admitted patients. The spread of day surgery providers in Slovakia is the result of the presented process. Therefore, our goal was a detailed analysis of the potential regional disparities in the provision of pediatric day surgery, with special focus on the trends in the number of procedures performed and the rate of subsequent hospital admission required after successful day surgery procedure (reflecting complexity of the cases and complications).

\section{Data Base and Methodology}

The basis of the analysis of the structure of pediatric day surgery was the data provided by NHIC provided on the base of our contractual cooperation - Annual Report $J$ (Ministry of Health) 1-01 about the medical care for the years 2009 to 2013 indicating the number of patients who were given the type of procedure according to the code of overnight healthcare, compiled from a list of procedures published 


\section{Tab. 1: Critical areas of pediatric day surgery development in Slovakia}

\section{Medical dimension
- Significant information asymmetry that results from healthcare specifications. \\ - Uneven distribution of technological and material equipment of the healthcare providers offering day surgery procedures, significant regional disparity - tendency towards induced demand. \\ - Inadequate medical education in the field of day surgery - small number of specialists, their uneven distribution, increasing financial demand of their work. \\ - Limited number of educational programs for students of 2nd and 3rd degree of higher education related to day surgery. \\ - Controlling the availability of the day surgery procedures by leasing (not leasing) contractual relationships with the health insurance companies and setting payment terms. \\ - High resistance of healthcare facilities in Slovakia to the implementation and expansion of day surgery. \\ - Incompatibility of available health care facilities hindering the development of day surgery.}

Availability of healthcare - fundamental barriers:

- Inconvenient geographical transport connections from remote places that prevent accessibility of control medical examination after day surgery procedures.

- Tendency to move the demand to private clinics at proclaimed favorable waiting times for some procedures, in which in complex cases the follow-up surveillance and treatment needs to be provided by state hospital.

- Administrative - heterogeneity in defining day surgery procedures for reporting those to health insurance companies (HIC).

\section{Economic dimension}

- Absence of motivation system in the hospitals to provide better quality and more cost-efficient healthcare via day surgery form.

- Economically difficult implementation of day surgery absence of inevitable financial support by the state.

- Uncertain return of investment into day surgery clinics development - short-term contracts with HICs.

- Absence of cost calculation for day surgery procedures in HCP's economics - reimbursement strategies of $\mathrm{HIC}$ and HCP are formed on the basis of lobbing and influenced by hospitals' ownerships and their legal form.

- Formation of health plans in accordance with the health policy of SR is not based on the grounds of inevitable analyses of healthcare availability.

- Tendency towards inducing demand from the providers of day surgery and price manipulation.

- Tendency to implement defensive diagnosis and testing (not leading towards the patient's health improvement) due to the complete absence of information about the risks associated with day surgery procedures for different groups of patients.

- Lack of interest to create costs calculations for the individual day surgery procedures as a consequence of given HIC prices that are hospital specific. (Hospitals are forced to prefer the payment for hospitalization, which is much higher than the one for day surgery procedure).

- Price differentiation of day surgery procedures depending on HIC ownerships (private vs. state owned) and HICs pressure to provide certain types of procedures only in form of day surgery; payment provided only at the rate of day surgery procedures despite complexity of some cases requiring subsequent admission to hospital - degradation of motivation of the providers to develop day surgery programme.

- Unclear pricing policy of the HICs and determination of price incompatibility by the lack of standardization of the procedures. in the Bulletin of the Ministry of Health dated to 2006-03-01, volume 9-16, part 23 Professional Guideline of the Ministry of Health about performance of day surgery. The basic structure of the report is shown in Table 2.

The data represents the aggregation of surgical procedures in Slovakia from 20092013. Due to the system of recording the data by the NHIC it is not possible to obtain recent data in presence. The data was structured in the form containing the frequency of the given procedures for the period (year) and region and aggregated for the whole country. The Bulletin of the Ministry of Health presents seven fields of overnight healthcare: surgery, orthopedics, trauma surgery and plastic surgery (SURG), Obstetrics and Gynecology (GYN), ophthalmology (OPHT), otolaryngology (ORL), urology (UROL), dental medicine and gastroenterological surgery and gastroenterology. Number of procedures in the last two fields is recognized at minimum numbers and therefore, it was not included in the analysis. Contingency table (Table 3 ) was 


\begin{tabular}{|c|c|c|c|c|c|c|}
\hline Tab. 2: & \multicolumn{6}{|c|}{$\begin{array}{l}\text { Sample of the structure of the Annual Report } \mathrm{J} \text { (Ministry of Health) 1-01 } \\
\text { and Bulletin of the Ministry of Health - Professional Guideline of the Ministry } \\
\text { of Health about performance of day surgery }\end{array}$} \\
\hline \multirow{3}{*}{\multicolumn{2}{|c|}{$\begin{array}{l}\text { Types of day } \\
\text { surgery } \\
\text { procedures }\end{array}$}} & \multirow{3}{*}{$\begin{array}{l}\text { Code of the } \\
\text { day surgery } \\
\text { procedures }\end{array}$} & \multicolumn{4}{|c|}{ Number of patients } \\
\hline & & & \multicolumn{2}{|c|}{ Operated } & \multicolumn{2}{|c|}{$\begin{array}{l}\text { Hospitalized after surgery } \\
\text { (from that) }\end{array}$} \\
\hline & & & 0-18 & $19+$ & $0-18$ & $19+$ \\
\hline \multicolumn{2}{|c|}{ Procedures } & a & 1 & 2 & 3 & 4 \\
\hline
\end{tabular}

Source: NHIC

created as the platform for processing the graphic output from the analysis. Analyses and graphical outputs were performed using the $R$ Project for Statistical Computing software and Excel and were carried out for the period of 2009-2013.

\section{Results and Evaluation}

In terms of the evolution of the structure of pediatric day surgery in Slovakia in the analyzed period, otolaryngology and surgery are dominant fields. In obstetrics in 2011, alternating increase and decrease in the number of procedures was recorded, while in 2010 to 2012 the number of admissions necessary after the day surgery procedure increased. In this timeframe, the number of admissions grew also in the field of surgery and gynecology. If the total number of admissions is focused on, most notably uneven trend in the number of hospitalized patients and outpatients was recorded in the field of surgery and otolaryngology. Ratio between the number of hospitalized patients and the total number of operated patients defines the rate of hospitalization of patients after day surgery procedure and thus the complexity of the procedure that cannot be assessed regardless the absolute frequency of its occurrence. High risk procedure, frequency of which can be counted in units, is economically irrelevant compared to the procedure with moderate risk of $10 \%$ to $20 \%$ and frequency in thousands. Table 3 presents the aggregated numbers of procedures of pediatric day surgery in various regions of Slovakia, as well as for the whole country.

The highest complexity of the procedures in 2010 was recorded in the field of GYN (73\%) in Košice region, in 2011 in the field of ORL $(81 \%)$ in Banská Bystrica region, in 2012 in the field of GYN and OPHT (73\%) in the Nitra region and in 2013 in the field of ORL $(74 \%)$ in Banská Bystrica region and GYN (66\%) in the Košice region (Appendix 1). When assessing the admission rates in individual regions, the highest proportion was noted in Banská Bystrica region in the field of ORL $(65.6 \%)$, as well as GYN (58.7\%) and OPHT $(53.66 \%)$ in Nitra region. $100 \%$ admission rate detected in Banská Bystrica region in 2009 in the field of ORL requires separate interpretation (not a single procedure was performed as day surgery case). Payment to the health care provider for a day surgery procedure is the same regardless the need for possible subsequent admission. Therefore, it is questionable whether $100 \%$ hospitalization rate is not the result of adapting to the contractual prices of HICs in the given year by a voluntary transfer of day surgery cases into the traditional hospitalization group, in order to receive higher payment for the procedure. That is why health insurance companies pricing policy may be considered a clear barrier for development of day surgery in Slovakia. Subsequently, analysis was focused on the regional disparity in numbers of pediatric day surgery procedures performed in each year according to specialties and hospitalization/ non-hospitalization after day surgery procedure (Appendix 2 and Figure 3).

The most dynamic development in the analyzed period was recorded in all regions in the fields of surgery and otolaryngology, in Košice region also in the field of urology. Urology procedures constitute the second most numerous group of procedures in this region, although a permanent decline in the number of completed procedures was recorded from 2011 till 2013. It is associated with morbidity of these procedures in the region, with minimal 


\section{Tab. 3: Pediatric day surgery procedures performed in the years 2009-2013 (Part 1)}

\begin{tabular}{|c|c|c|c|c|c|c|c|c|c|c|c|c|}
\hline \multirow{3}{*}{$\begin{array}{r}\text { Yea } \\
2009\end{array}$} & \multirow{2}{*}{\multicolumn{2}{|c|}{ Field of expertise }} & \multirow[b]{2}{*}{ Patients } & \multicolumn{8}{|c|}{ Region } & \multirow[b]{2}{*}{ Total } \\
\hline & & & & $B C$ & $\mathrm{BL}$ & $\mathrm{KI}$ & NI & PV & TA & TC & Zl & \\
\hline & SURG & & Hospitalized & 1 & 1 & 6 & 1 & 1 & 0 & 10 & 2 & 22 \\
\hline & & & Nonhospitalized & 87 & 441 & 307 & 15 & 72 & 71 & 77 & 220 & 1,290 \\
\hline & & \multicolumn{2}{|l|}{ Total } & 88 & 442 & 313 & 16 & 73 & 71 & 87 & 222 & 1,312 \\
\hline & \multirow[t]{3}{*}{ GYN } & & Hospitalized & 0 & 2 & 12 & 0 & 0 & - & 0 & 0 & 14 \\
\hline & & & Nonhospitalized & 15 & 11 & 12 & 18 & 21 & - & 15 & 92 & 184 \\
\hline & & Total & & 15 & 13 & 24 & 18 & 21 & - & 15 & 92 & 198 \\
\hline & \multirow[t]{3}{*}{ OPHT } & & Hospitalized & 2 & - & 0 & - & 0 & - & - & 0 & 2 \\
\hline & & & Nonhospitalized & 9 & - & 14 & - & 9 & - & - & 32 & 64 \\
\hline & & Total & & 11 & - & 14 & - & 9 & - & - & 32 & 66 \\
\hline & \multirow[t]{3}{*}{ ORL } & & Hospitalized & 482 & 93 & 62 & 0 & 0 & 0 & 4 & 0 & 641 \\
\hline & & & Nonhospitalized & 0 & 1,002 & 444 & 202 & 606 & 2 & 68 & 479 & 2,803 \\
\hline & & Total & & 482 & 1,095 & 506 & 202 & 606 & 2 & 72 & 479 & 3,444 \\
\hline & \multirow[t]{3}{*}{ UROL } & & Hospitalized & 0 & - & 0 & 0 & 0 & 1 & 0 & 0 & 1 \\
\hline & & & Nonhospitalized & 8 & - & 750 & 12 & 2 & 133 & 27 & 67 & 999 \\
\hline & & Total & & 8 & - & 750 & 12 & 2 & 134 & 27 & 67 & 1,000 \\
\hline & \multirow[t]{3}{*}{ Total } & & Hospitalized & 485 & 96 & 80 & 1 & 1 & 1 & 14 & 2 & 680 \\
\hline & & & Nonhospitalized & 119 & 1,454 & 1,527 & 247 & 710 & 206 & 187 & 890 & 5,340 \\
\hline & & Total & & 604 & 1,550 & 1,607 & 248 & 711 & 207 & 201 & 892 & 6,020 \\
\hline \multirow[t]{17}{*}{2010} & \multirow[t]{3}{*}{ SURG } & & Hospitalized & 5 & 0 & 0 & 11 & 55 & 0 & 48 & 0 & 119 \\
\hline & & & Nonhospitalized & 75 & 142 & 299 & 69 & 89 & 105 & 200 & 320 & 1,299 \\
\hline & & Total & & 80 & 142 & 299 & 80 & 144 & 105 & 248 & 320 & 1,418 \\
\hline & \multirow[t]{3}{*}{ GYN } & & Hospitalized & 0 & 0 & 11 & 0 & 0 & 0 & 0 & 0 & 11 \\
\hline & & & Nonhospitalized & 10 & 9 & 4 & 29 & 138 & 2 & 1 & 64 & 257 \\
\hline & & Total & & 10 & 9 & 15 & 29 & 138 & 2 & 1 & 64 & 268 \\
\hline & \multirow[t]{3}{*}{ OPHT } & & Hospitalized & 0 & 6 & 0 & 0 & 0 & 0 & - & 0 & 6 \\
\hline & & & Nonhospitalized & 2 & 36 & 23 & 1 & 12 & 1 & - & 28 & 103 \\
\hline & & Total & & 2 & 42 & 23 & 1 & 12 & 1 & - & 28 & 109 \\
\hline & \multirow[t]{3}{*}{ ORL } & & Hospitalized & 0 & 118 & 111 & 0 & 0 & 1 & 25 & 5 & 260 \\
\hline & & & Nonhospitalized & 479 & 767 & 708 & 488 & 1043 & 77 & 218 & 574 & 4,354 \\
\hline & & Total & & 479 & 885 & 819 & 488 & 1043 & 78 & 243 & 579 & 4,614 \\
\hline & UROL & & Nonhospitalized & 4 & 18 & 956 & 17 & 4 & 127 & 28 & 232 & 1,386 \\
\hline & & Total & & 4 & 18 & 956 & 17 & 4 & 127 & 28 & 232 & 1,386 \\
\hline & Total & & Hospitalized & 5 & 124 & 122 & 11 & 55 & 1 & 73 & 5 & 396 \\
\hline & & & Nonhospitalized & 570 & 972 & 1,990 & 604 & 1,286 & 312 & 447 & 1,218 & 7,399 \\
\hline & & Total & & 575 & 1,096 & 2,112 & 615 & 1,341 & 313 & 520 & 1,223 & 7,795 \\
\hline
\end{tabular}




\section{Ekonomika a management}

\section{Tab. 3: Pediatric day surgery procedures performed in the years 2009-2013 (Part 2)}

\begin{tabular}{|c|c|c|c|c|c|c|c|c|c|c|c|c|}
\hline \multirow{3}{*}{$\begin{array}{c}\text { Year } \\
2011\end{array}$} & \multirow{2}{*}{\multicolumn{2}{|c|}{$\begin{array}{l}\text { Field of } \\
\text { expertise }\end{array}$}} & \multirow{2}{*}{ Patients } & \multicolumn{8}{|c|}{ Region } & \multirow{2}{*}{ Total } \\
\hline & & & & \multirow{2}{*}{ BC } & \multirow{2}{*}{ BL } & \multirow{2}{*}{$\begin{array}{r}\text { KI } \\
67\end{array}$} & \multirow{2}{*}{$\begin{array}{ll}\text { NI } & \\
& 49\end{array}$} & \multirow{2}{*}{$\begin{array}{l}\text { PV } \\
212\end{array}$} & \multirow{2}{*}{$\begin{array}{r}\text { TA } \\
50\end{array}$} & \multirow{2}{*}{$\begin{array}{r}\text { TC } \\
10\end{array}$} & \multirow{2}{*}{$\begin{array}{r}\text { ZI } \\
66\end{array}$} & \\
\hline & SURG & & Hospitalized & & & & & & & & & 458 \\
\hline & & & Nonhospitalized & 391 & 305 & 386 & 96 & 173 & 429 & 257 & 487 & 2,524 \\
\hline & & \multicolumn{2}{|c|}{ Total } & 391 & 309 & 453 & 145 & 385 & 479 & 267 & 553 & 2,982 \\
\hline & \multirow[t]{3}{*}{ GYN } & & Hospitalized & 0 & - & 75 & 0 & 0 & 9 & 0 & 0 & 84 \\
\hline & & & Nonhospitalized & 10 & - & 50 & 68 & 14 & 18 & 14 & 21 & 195 \\
\hline & & Tota & & 10 & - & 125 & 68 & 14 & 27 & 14 & 21 & 279 \\
\hline & \multirow[t]{3}{*}{ OPHT } & & Hospitalized & 0 & - & 25 & 0 & 0 & - & 0 & 0 & 25 \\
\hline & & & Nonhospitalized & 7 & - & 46 & 8 & 31 & - & 2 & 60 & 154 \\
\hline & & Tota & & 7 & - & 71 & 8 & 31 & - & 2 & 60 & 179 \\
\hline & \multirow[t]{3}{*}{ ORL } & & Hospitalized & 523 & 2 & 0 & 0 & 91 & 27 & 51 & 1 & 695 \\
\hline & & & Nonhospitalized & 123 & 831 & 1,249 & 215 & 2,270 & 275 & 484 & 1,256 & 6,703 \\
\hline & & Tota & & 646 & 833 & 1,249 & 215 & 2,361 & 302 & 535 & 1,257 & 7,398 \\
\hline & \multirow[t]{3}{*}{ UROL } & & Hospitalized & 0 & 0 & 0 & 0 & 0 & 2 & 0 & 0 & 2 \\
\hline & & & Nonhospitalized & 1 & 9 & 1,174 & 78 & 26 & 163 & 25 & 118 & 1,594 \\
\hline & & Tota & & 1 & 9 & 1,174 & 78 & 26 & 165 & 25 & 118 & 1,596 \\
\hline & \multirow[t]{3}{*}{ Total } & & Hospitalized & 523 & 6 & 167 & 49 & 303 & 88 & 61 & 67 & 1,264 \\
\hline & & & Nonhospitalized & 532 & 1,145 & 2,905 & 465 & 2,514 & 885 & 782 & 1,942 & 11,170 \\
\hline & & Tota & & 1,055 & 1,151 & 3,072 & 514 & 2,817 & 973 & 843 & 2,009 & 12,434 \\
\hline \multirow[t]{18}{*}{2012} & \multirow[t]{3}{*}{ SURG } & & Hospitalized & 31 & 180 & 175 & 85 & 48 & 51 & 20 & 177 & 767 \\
\hline & & & Nonhospitalized & 467 & 453 & 269 & 104 & 253 & 171 & 192 & 550 & 2,459 \\
\hline & & Tota & & 498 & 633 & 444 & 189 & 301 & 222 & 212 & 727 & 3,226 \\
\hline & \multirow[t]{3}{*}{ GYN } & & Hospitalized & 0 & - & 104 & 22 & 0 & 11 & 0 & 4 & 141 \\
\hline & & & Nonhospitalized & 71 & - & 93 & 8 & 30 & 6 & 15 & 17 & 240 \\
\hline & & Tota & & 71 & - & 197 & 30 & 30 & 17 & 15 & 21 & 381 \\
\hline & \multirow[t]{3}{*}{ OPHT } & & Hospitalized & 0 & 0 & 0 & 22 & 0 & - & 0 & 0 & 22 \\
\hline & & & Nonhospitalized & 8 & 3 & 49 & 8 & 42 & - & 4 & 54 & 168 \\
\hline & & Tota & & 8 & 3 & 49 & 30 & 42 & - & 4 & 54 & 190 \\
\hline & \multirow[t]{3}{*}{ ORL } & & Hospitalized & 280 & 0 & 0 & 67 & 218 & 156 & 2 & 335 & 1,058 \\
\hline & & & Nonhospitalized & 148 & 615 & 1,532 & 726 & 1,883 & 359 & 536 & 1,491 & 7,290 \\
\hline & & Tota & & 428 & 615 & 1,532 & 793 & 2,101 & 515 & 538 & 1,826 & 8,348 \\
\hline & UROL & & Hospitalized & 5 & 0 & 45 & 5 & 1 & 29 & 6 & 0 & 91 \\
\hline & & & Nonhospitalized & 6 & 19 & 786 & 170 & 38 & 149 & 41 & 136 & 1,345 \\
\hline & & Tota & & 11 & 19 & 831 & 175 & 39 & 178 & 47 & 136 & 1,436 \\
\hline & Total & & Hospitalized & 316 & 180 & 324 & 201 & 267 & 247 & 28 & 516 & 2,079 \\
\hline & & & Nonhospitalized & 700 & 1,090 & 2,729 & 1,016 & 2,246 & 685 & 788 & 2,248 & 11,502 \\
\hline & & Tota & & 1,016 & 1,270 & 3,053 & 1,217 & 2,513 & 932 & 816 & 2,764 & 13,581 \\
\hline
\end{tabular}




\section{Tab. 3: Pediatric day surgery procedures performed in the years 2009-2013 (Part 3)}

\begin{tabular}{|c|c|c|c|c|c|c|c|c|c|c|c|c|}
\hline \multirow{3}{*}{$\begin{array}{l}\text { Year } \\
2013\end{array}$} & \multirow{2}{*}{\multicolumn{2}{|c|}{$\begin{array}{l}\text { Field of } \\
\text { expertise }\end{array}$}} & \multirow{2}{*}{ Patients } & \multicolumn{8}{|c|}{ Region } & \multirow{2}{*}{ Total } \\
\hline & & & & & \multirow{2}{*}{ BL } & \multirow{2}{*}{$\begin{array}{l}\text { KI } \\
151\end{array}$} & \multirow{2}{*}{$\begin{array}{l}\text { NI } \\
58\end{array}$} & \multirow{2}{*}{$\begin{array}{r}\text { PV } \\
141\end{array}$} & \multirow{2}{*}{$\begin{array}{l}\text { TA } \\
46\end{array}$} & \multirow{2}{*}{$\begin{array}{l}\text { TC } \\
36\end{array}$} & \multirow{2}{*}{\begin{tabular}{|l} 
ZI \\
\\
\end{tabular}} & \\
\hline & SURG & & Hospitalized & & & & & & & & & 518 \\
\hline & & & Nonhospitalized & 448 & 496 & 323 & 166 & 385 & 130 & 447 & 430 & 2,825 \\
\hline & & \multicolumn{2}{|c|}{ Total } & 448 & 496 & 474 & 224 & 526 & 176 & 483 & 516 & 3,343 \\
\hline & \multirow[t]{3}{*}{ GYN } & & Hospitalized & 0 & 0 & 95 & 5 & 2 & - & 0 & 0 & 102 \\
\hline & & & Nonhospitalized & 40 & 7 & 50 & 13 & 23 & - & 17 & 7 & 157 \\
\hline & & \multicolumn{2}{|c|}{ Total } & 40 & 7 & 145 & 18 & 25 & - & 17 & 7 & 259 \\
\hline & \multirow[t]{3}{*}{ OPHT } & & Hospitalized & - & 0 & 0 & 0 & 0 & - & 0 & 4 & 4 \\
\hline & & & Nonhospitalized & - & 24 & 37 & 2 & 39 & - & 4 & 50 & 156 \\
\hline & & \multicolumn{2}{|c|}{ Total } & - & 24 & 37 & 2 & 39 & - & 4 & 54 & 160 \\
\hline & \multirow[t]{3}{*}{ ORL } & & Hospitalized & 458 & 0 & 0 & 12 & 0 & 29 & 12 & 0 & 511 \\
\hline & & & Nonhospitalized & 165 & 286 & 1,568 & 436 & 2,683 & 98 & 413 & 1,455 & 7,104 \\
\hline & & Tota & & 623 & 286 & 1,568 & 448 & 2,683 & 127 & 425 & 1,455 & 7,615 \\
\hline & \multirow[t]{3}{*}{ UROL } & & Hospitalized & 0 & 0 & 55 & 14 & 11 & 28 & 14 & 0 & 122 \\
\hline & & & Nonhospitalized & 13 & 2 & 674 & 20 & 90 & 166 & 26 & 206 & 1,197 \\
\hline & & Tota & & 13 & 2 & 729 & 34 & 101 & 194 & 40 & 206 & 1,319 \\
\hline & \multirow[t]{3}{*}{ Total } & & Hospitalized & 458 & 0 & 301 & 89 & 154 & 103 & 62 & 90 & 1,257 \\
\hline & & & Nonhospitalized & 666 & 815 & 2,652 & 637 & 3,220 & 394 & 907 & 2,148 & 11,439 \\
\hline & & Tota & & 1,124 & 815 & 2,953 & 726 & 3,374 & 497 & 969 & 2,238 & 12,696 \\
\hline \multirow[t]{18}{*}{ Total } & \multirow[t]{3}{*}{ SURG } & & Hospitalized & 37 & 185 & 399 & 204 & 457 & 147 & 124 & 331 & 1884 \\
\hline & & & Nonhospitalized & 1,468 & 1,837 & 1,584 & 450 & 972 & 906 & 1,173 & 2,007 & 10,397 \\
\hline & & Tota & & 1,505 & 2,022 & 1,983 & 654 & 1,429 & 1,053 & 1,297 & 2,338 & 12,281 \\
\hline & \multirow[t]{3}{*}{ GYN } & & Hospitalized & 0 & 2 & 297 & 27 & 2 & 20 & 0 & 4 & 352 \\
\hline & & & Nonhospitalized & 146 & 27 & 209 & 136 & 226 & 26 & 62 & 201 & 1,033 \\
\hline & & Tota & & 146 & 29 & 506 & 163 & 228 & 46 & 62 & 205 & 1,385 \\
\hline & OPHT & & Hospitalized & 2 & 6 & 25 & 22 & 0 & 0 & 0 & 4 & 59 \\
\hline & & & Nonhospitalized & 26 & 63 & 169 & 19 & 133 & 1 & 10 & 224 & 645 \\
\hline & & Tota & & 28 & 69 & 194 & 41 & 133 & 1 & 10 & 228 & 704 \\
\hline & ORL & & Hospitalized & 1,743 & 213 & 173 & 79 & 309 & 213 & 94 & 341 & 3165 \\
\hline & & & Nonhospitalized & 915 & 3,501 & 5,501 & 2,067 & 8,485 & 811 & 1,719 & 5,255 & 28,254 \\
\hline & & Tota & & 2,658 & 3,714 & 5,674 & 2,146 & 8,794 & 1,024 & 1,813 & 5,596 & 31,419 \\
\hline & UROL & & Hospitalized & 5 & 0 & 100 & 19 & 12 & 60 & 20 & 0 & 216 \\
\hline & & & Nonhospitalized & 32 & 48 & 4,340 & 297 & 160 & 738 & 147 & 759 & 6,521 \\
\hline & & Tota & & 37 & 48 & 4,440 & 316 & 172 & 798 & 167 & 759 & 6,737 \\
\hline & Total & & Hospitalized & 1,787 & 406 & 994 & 351 & 780 & 440 & 238 & 680 & 5676 \\
\hline & & & Nonhospitalized & 2,587 & 5,476 & 11,803 & 2,969 & 9,976 & 2,482 & 3,111 & 8,446 & 46,850 \\
\hline & & Tota & & 4,374 & 5,882 & 12,797 & 3,320 & 10,756 & 2,922 & 3,349 & 9,126 & 52,526 \\
\hline
\end{tabular}

Abbreviations to the table:

Source: processed under NHIC database

\section{Field of expertise:}

SURG: Surgery, Orthopedics, Department of Trauma and Plastic Surgery, GYN: Gynaecology and Obstetrics, OPHT: Ophthalmology, ORL: Otorhinolaryngology, UROL: Urology.

Region: BC: Banská Bystrica, BL: Bratislava, KI: Košice, NI: Nitra, PV: Prešov, TA: Trnava, TC: Trenčín, ZI: Žilina. 


\section{Fig. 3: Process development of pediatric day surgery by regions}

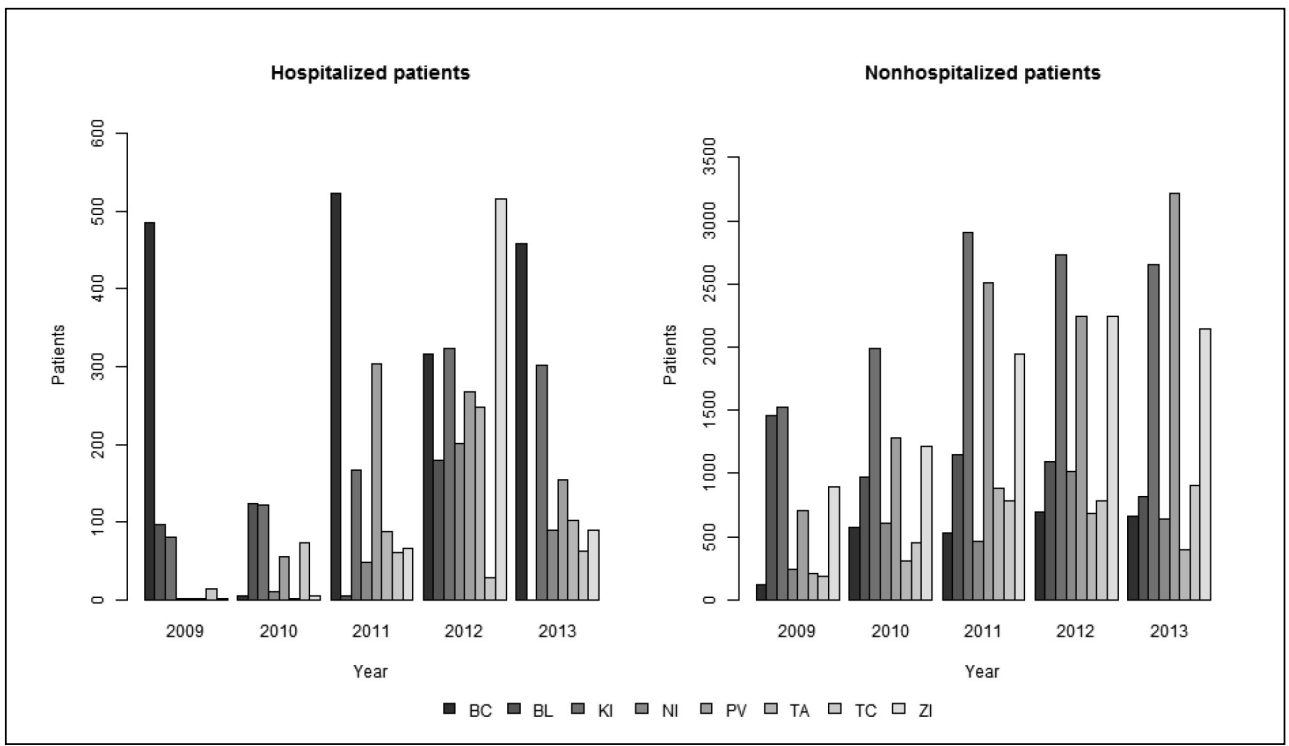

Source: own

frequency of these procedures in Bratislava and Banská Bystrica region. From the trends in the number of hospitalized patients and outpatients shown in Figure 3, the annual differences are extremely disproportional, especially in the group of hospitalized patients in all Slovak regions, except Trenčín region. This observation probably reflects pricing policy of health insurance companies which set prices regardless the complexity of the procedure, without any realistic calculations of the costs. Those should also include increased complexity of the procedure in the specific patient groups (based on age, comorbidities, BMI, etc.). The absence of these calculations in the challenging environment during the process of reduction of hospital facilities, in the environment of high instability in contractual relations of hospitals and health insurance companies, force the providers to misuse reporting methodology by transfer of day surgery procedures into threeday surgery or multi-day surgery system. In the overall assessment of the development of hospitalization of pediatric patients in all regions and fields, positive trend can be noted - a relatively stable development in the number of outpatient procedures and slight decrease in the number of hospitalized patients. Aggregated data that is summarized in Figure 4 has limited interpretation value, as it is of utmost importance to reflect anomalies in development across regions, both in the trend in the pediatric day surgery performance as well as in the structure of the procedures provided.

It is very unlikely that these anomalies in the development of hospitalization in the referred regions are supported by relevant morbidity of the region's inhabitants. If the complexity of the day surgery procedures in the given regions is significantly higher, it is then questionable whether it is appropriate to provide day surgery there. Consequently, it would be appropriate to reconsider the structure of the bed fund in hospitals in these areas. Although the Ministry of Health declares a balanced regional distribution of Slovak health needs (based on this premise and taking into account migration for health care), the results of analyzes of regional differences and of the process structure of performed procedures show substantial discrepancies in the policies of individual hospitals. 


\section{Fig. 4: Development of pediatric day surgery in Slovakia}

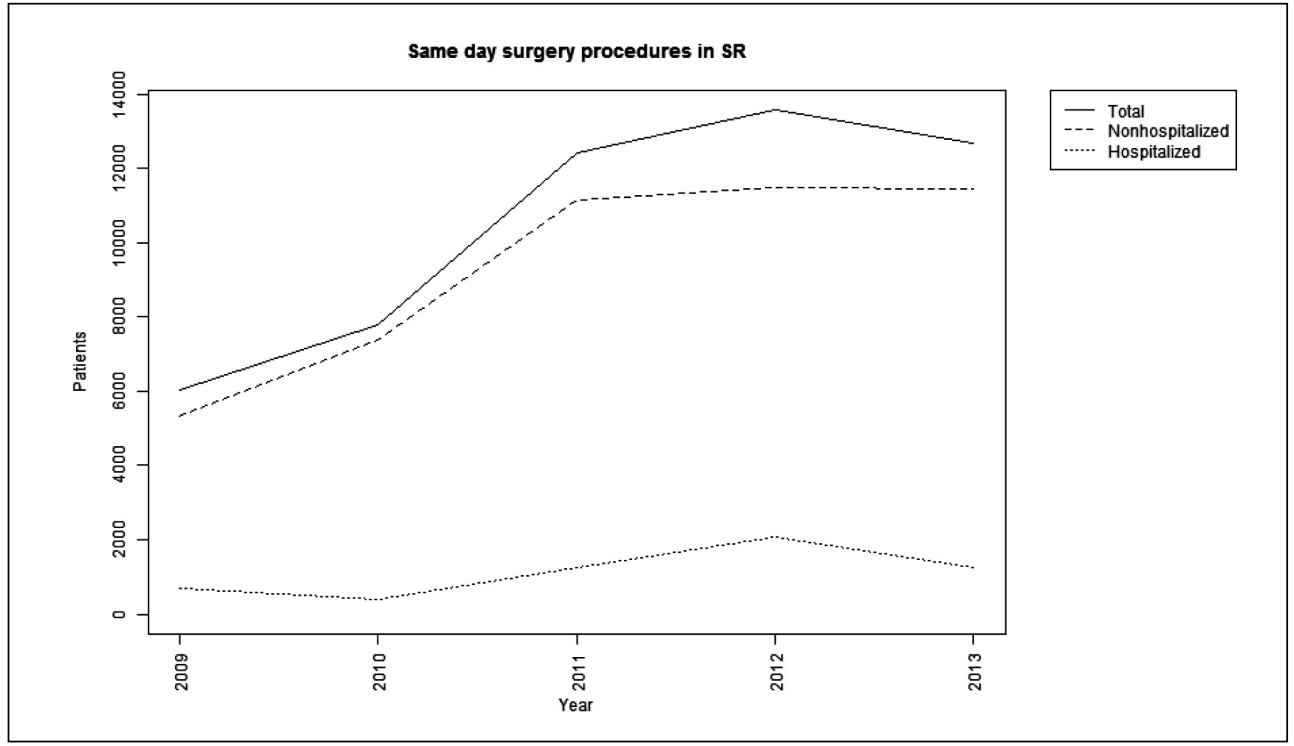

Source: own

\section{Discussion}

Day surgery in Slovakia has been poorly regulated for a long time. Despite continuous legislative support of day surgery system by the Ministry of Health, its proportion is very low compared to other countries and fails to show positive progress. The reasons can be identified in three dimensions: medical and economic in the pediatric population plus social in the adult one. Each of these dimensions interacts with the availability of healthcare in Slovakia, with the quality of the provided care, with the economic cost-benefit ratio, efficiency and equality. Setting up an active health policy on the global country level requires finding a balance among mentioned variables, which is very problematic (Zelený \& Bencko, 2015; Aslani et al., 2015). Our analysis revealed uneven trend in distribution of completed pediatric day surgery procedures in different regions. It is very difficult to explain relevant reasons for this observation. One possible explanation is deliberate misuse of reporting methodology by healthcare providers due to the current pricing strategies of three health insurance companies operating in Slovakia.
Many hospitals purposefully transfer day surgery procedures into the group of specially paid procedures (SPP - patient admitted to the hospital for up-to 72 hours) because the payment for SPP is considerably higher compared to day surgery. This is deep systemic problem related to the policy of price making, short-term contractual relationships between primary healthcare and health insurance companies as well as other causes (legislative, procedural, etc.). The issues mentioned above will not be solved by the planned adoption of German Diagnoses Related Groups (DRG) classification in Slovakia which is planned in 2015 as this system does not contain day surgery procedures. As such, those will have to be dealt with separately. Based on the observed regional differences in the number and structure of pediatric day surgery procedures performed, it may seem appropriate to transform some small hospitals into the units of day surgery, providing essentially the same spectrum of the procedures except for complex rare ones, thereby reducing the costs. As regards the access to pediatric day surgery in Slovakia, it is largely influenced by the dictate of HICs. In case that the HICs do not sign the contract with the 
healthcare provider, majority of surgeons would recommend performing the procedure during the traditional hospital admission because they do not consider ethical to make the patient pay for the procedure that may actually be provided free of charge. Pricing strategies are strongly influenced by the type of ownership of HICs. Different payments are set for different providers without any clear criteria. As such, private HICs favor private healthcare providers. Furthermore, the absence of standardization of day surgery procedures makes it difficult to assess their real costs.

In connection with the presented outcomes, it is important to draw attention to the issues related to the reporting data from NHIC that were made available for analysis based on our cooperation. NHIC plans adjustment of reports in 2015; therefore, the output of our analysis will be a proposal to amend the system in order to implement default parameters adopted in developed countries and to follow relevant outcomes with the possibility of benchmarking (both performance and strategic). By achieving this change in reporting, possibility for highly effective multivariate economic and medical analysis would be created. The outcomes of such analyses would be beneficial for the development of process management in hospitals and would allow more efficient healthcare provision by better definition of the risky population subgroups not suitable for day procedures. Complexity of different types of procedures could also be better described. Such an approach would allow setting up the benchmarking parameters for performance, efficiency and quality of healthcare.

These problematic issues of day surgery development have highly systemic character, both on the national and international level, and it is essential to incorporate them into the strategic plans of health system development. Only such an approach may promote the development of day surgery in Slovakia, comparable with other countries.

\section{Conclusion}

In the last two decades, there has been reduction of hospital beds and the average length of hospital stay in majority of European countries (Dlouhý \& Barták, 2013). The intensity of this process was uneven, as declared by the considerable differences among countries, both in terms of the total amount of hospital expenditures, the average length of stay, the proportion of day surgery procedures, etc. Analyzing the problem of day surgery efficiency in any healthcare system is very difficult, due to the conceptual and methodological problems of its measurement. These difficulties were already recognized by international institutions such as Eurostat, OECD and WHO that have been collecting data on surgical procedures for several years, as a part of the overall data collection activities in healthcare. Even fifteen years after its introduction, the utilization rate of pediatric day surgery is very low in Slovakia. Possible reasons include poorly implemented systemic measures for its development, low level of specialization of healthcare providers, unclear pricing and preferential criteria of HICs, insufficient social support related to subsequent postoperative care, etc. Furthermore, analysis of the impact of comorbidities on the performance of day surgery, as well as the punctual assessment of the results of performed procedures is missing. Future progress will not be possible without effective analysis and subsequent penetration of the outputs into the system of day surgery via implementing those into the priorities of the Slovak healthcare system. Our analysis detected significant regional disparities in the number of day surgery procedures in various surgical specialties and years. Analysis of admission rates (which defines the complexity of the procedure) in different regions confirmed extreme inter-annual fluctuations in the numbers of admitted pediatric patients after the procedure. The complexity of the procedure should define the additional financial requirements and hence the rationale to include specific type of procedure into the day surgery concept in the given region. It is still questionable whether the admission rate is actually reflecting the complexity of the procedure or it is the result of adapting to the contractual prices of HICs in a given year by the voluntary decision of the provider not to perform the procedure as one-day surgery due to financial reasons. Obviously, pricing strategy of HICs in terms of financing the procedures of day surgery plays an important role in its development. Nevertheless, in general, pediatric day surgery in Slovakia has good conditions for its future development. Current achievements in medical science intervene in the process of day surgery development by improved patient selection, 
preoperative and postoperative care, pain relief and by the penetration of minimally invasive surgical techniques, ensuring the reduction of operating time, thus allowing more procedures be suitable for day surgery. Based on the facts mentioned it can be concluded that systematic and systemic implementation of day surgery in Slovakia is still a great challenge for all involved subjects, despite the substantial progress in the organization of health care system.

This work was supported by the VEGA Project No. 1/0929/14 "Multidimensional economic and financial evaluation of the implementation process and the use of one day health care and quantification of the financial impact on the health care system in the Slovak Republic".

Our thanks goes out to the National Health Information Center (NHIC) of Slovakia for providing access to the central mortality database for the studied period as well as other studied data along with the Statistical Office of the Slovak.

\section{References}

Aslani, A., Zolfagharzadeh, M.M., \& Naaranoja, M. (2015). Key Items of Innovation Management in the Primary Healthcare Centres Case Study: Finland. Cent Eur J Public Health, 23(3),183-187.

Aldwinckle, R.J., \& Montgomery, J.E. (2004). Unplanned admission rates and postdischarge complications in patients over the age of 70 following day case surgery. Anaesthesia, 59(1), 57-59. doi:10.1111/j.1365-2044.2004.03560.x.

Babala, J. (2014, March 21). Jednodňová chirurgia - novinky v legislatíve. detskechoroby. rodinka.sk. Retrieved July 28, 2014, from http:// detskechoroby.rodinka.sk/detske-choroby/ zdravotnictvo/zakroky/jednodnova-chirurgia/.

Calland, J.F., et al. (2001). Outpatient laparoscopic cholecystectomy: patient outcomes after implementation of a clinical pathway. Ann Surg., 233(5), 704-715. doi:10.1097/00000658-200105000-00015.

Castoro, C., Bertinato, L., Baccaglini, U., Drace, C.A., \& McKee, M., et al. (2007). Policy Brief. Day surgery: making it happen. Brussels: WHO European Centre for Health Policy. Retrieved July 26, 2014, from http://www.euro. who.int/_data/assets/pdf_file/0011/108965/ E90295.pdf.

Castells, X., Alonso, J., \& Castilla, M., et al. (2001). Outcomes and costs of outpatient and inpatient cataract surgery: a randomised clinical trial. J Clin Epidemiol, 54(1), 23-29. doi:10.1016/s0895-4356(00)00271-7.

Corvera, G., Gespedes, B., \& Ysunza, A., et al. (1996). Ambulatory vs. in-patient stapedectomy: a randomized twenty-patient pilot study. Otolaryngol Head Neck Surg., 114(3), 355-359. doi:10.1016/s0194-5998(96)70203-6.

Coley, K.C., Wiliams, B.A., \& DaPOS, S.V., et al. (2002). Retrospective evaluation of unanticipated admissions and readmissions after same day surgery and associated costs. J Clin Anesth, 14(5), 349-353. doi:10.1016/ s0952-8180(02)00371-9.

Cullen, K.A., Hall, M.J., \& Golosinskiy, A. (2009). Ambulatory surgery in the United States (National health statistics reports; no 11). Hyattsville, MD: National Center for Health Statistics. Retrieved July, 20, 2014, from http:// www.cdc.gov/nchs/data/nhsr/nhsr011.pdf.

Davies, K.E., Houghton, K., \& Montgomery, J.E. (2001). Obesity and day-case surgery. Anaesthesia, 56(11), 1090-1115. doi:10.1111/ j.1365-2044.2001.1962-5.x.

Dlouhý, M., \& Barták, M. (2013). Mental Health Financing in Six Eastern European Countries. E\&M Ekonomie a Management, 16(4), 4-13.

Eckhardtová, M. (2014). Štát a poist'ovne nám hádžu polená pod nohy. Retrieved July 22, 2014, from http://www.farmakoekonomika.sk/ images/stories/tlacovy_monitor/zn/DT_2011/ zn_12/27_03_22t.htm.

Fan, Y.P., Boldy, D., \& Bowen, D. (1997). Comparing patient satisfaction, outcomes and costs between cataract day surgery and inpatient surgery for elderly people. Aust Health $R e, 20(4), 27-39$. doi:10.1071/ah970027.

Fedorowicz, Z., Lawrence, D., \& Gutierrez, P. (2005). Day care versus inpatient surgery for age-related cataract (Art. No.: CD004242). Cochrane Database of Systematic Reviews. doi:10.1002/14651858.CD004242.pub3.

Fleisher, L.A., Pasternak, L.R., Herbert, R., \& Anderson, G.F. (2004). Inpatient hospital admission and death after outpatient surgery in elderly patients: importance of patient and system characteristics and location of care. Arch Surgm., 139(1), 67-72. doi:10.1001/ archsurg.139.1.67.

Gavurová, B., \& Hyránek, E. (2013). Determinanty rozvoja jednodňovej zdravotnej starostlivosti na Slovensku. Ekonomický časopis, 61(2),134-154. 
Gavurová, B., Klepáková, A., \& Ivančová, L. (2013). Day Surgery Development Aspects in Slovakia. Estudios de Economia Aplicada. 31(2), 477-496.

Hicklin, L., Tostevin, P.M., \& Wyatt, M.E. (1999). Parental satisfaction with paediatric day-case ENT surgery. J Laryngol Otol, 113(12), 1072-1075. doi:10.1017/s0022215100157925.

Hollington, P., Toogood, G.J., \& Padbury, R.T. (1999). A prospective randomized trial of day-stay only versus overnight-stay laparoscopic cholecystectomy. Aust N Z J Surg., 69(12), 841843. doi:10.1046/j.1440-1622.1999.01713.x.

Hudecová, D. (2014, July 22). Záujem o jednodňovú chirurgiu rastie. Kde je výhodná?. pravda.sk. Retrieved July 22, 2014, from http://zdravie.pravda.sk/zdravie-a-prevencia/ clanok/12966-zaujem-o-jednodnovu-chirurgiurastie-kde-je-vyhodna/.

Hunt, L., Luck, A.J., \& Rudkin, G., et al. (1999). Day-case haemorrhoidectomy. $\mathrm{Br}$ JSurg., 86(2), 255-258. doi:10.1046/j.13652168.1999.01024.x.

Chung, F., Yuan, H., Yin, L., Vairavanathan, S., \& Wong, D.T. (2009). Elimination of preoperative testing in ambulatory surgery. Anesthesia \& Analgesia., 108(2), 467-475. doi:10.1213/ane.0b013e318176bc19.

IAAS [International Association for Ambulatory Surgery]. (2003). Clinical Indicators for Ambulatory Surgery. Retrieved July 12, 2014, from www.iaas-med.com.

Ivlev, I., Barták, M., \& Kneppo, P. (2014). Methodology for selecting expert groups for the purpose of decision making tasks. Value in Health, 17(7), A580. doi:10.1016/j.jval.2014.08.1961.

Jarrett, P.E.M., \& Roberts, L.M. (2006). Planning and designing a Day Surgery Unit. In P. Lemos, P. Jarrett, B. Philip (Eds.), Day Surgery Development and Practice (pp. 6187). London, UK: International Association for Ambulatory Surgery (IAAS).

Kurtinová, O. (2015). Self-perceived Health in the Czech Population: Recent Evidence. Cent Eur J Public Health, 23(1):45-53.

Lau, H., Poon, J., \& Lee, F. (2000). Patient satisfaction after ambulatory inguinal hernia repair in Hong Kong. Ambul Surg., 8(3), 115118. doi:10.1016/s0966-6532(99)00062-1.

Lemos, P., \& Regalado, A.M. (2006). Patient outcomes and clinical indicators for ambulatory surgery. In P. Lemos, P. Jarrett, B. Philip (Eds.), Day Surgery Development and Practice (257280). London, UK: International Association for
Ambulatory Surgery (IAAS).

McHugh, G.A., \& Thoms, G.M. (2002) The management of pain following daycase surgery. Anaesthesia, 57(3), 270-275. doi:10.1046/j.1365-2044.2002.2366_2.x.

Mezei, G., \& Chung, F. (1999). Return hospital visits and hospital readmissions after ambulatory surgery. Ann Surg., 230(5), 721727. doi:10.1097/00000658-199911000-00016.

Michalič, M. (2014). Jednodňová chirurgia má stále malé zastúpenie. primar.sme.sk. Retrieved July 12, 2014, from http://primar.sme. sk/c/4309535/jednodnova-chirurgia-ma-stalemalezastupenie.html \#ixzz22nEaN8QG.

Maresova, P., Mohelska, H., Dolejs, J., \& Kuca, K. (2015). Socio-economic Aspects of Alzheimer's Disease. Current Alzheimer Research, 12(9), 903-911.

Mohelska, H., Maresova, P., Valis, M., \& Kuca, K. (2015). Alzheimer's disease and its treatment costs: case study in the Czech Republic. Neuropsychiatric Disease and Treatment, 2015(11), 2349-2354. doi:10.2147/NDT.S87503.

Rusnáková, J., \& Rochovská, A. (2014). Segregácia obyvatel'ov marginalizovaných rómskych komunít, chudoba a znevýhodnenia súvisiace s priestorovým vylúčením. Geographia Cassoviensis, 8(2), 162-172.

Rusnáková, J. (2011). Vol'by životných stratégií obyvatel'ov chudobných a sociálne vylúčených rómskych osídlení. In J. Rusnáková (Ed.), Životné stratégie obyvatelov rómskych osidlení (41-95). Nitra: UKF.

Segerdahl, M., Warren-Stomberg, M., Rawal, N., Brattwall, M., \& Jakobsson, J. (2008). Clinical practice and routines for day surgery in Sweden: results from a nation-wide survey. Acta Anaesthesiol Scand., 52(1), 117124. doi:10.1111/j.1399-6576.2007.01472.x.

Shnaider, I., \& Chung, F. (2006). Outcomes in day surgery. Curr Opin Anaesthesiol, 19(6), 622-629.

Smith, I., McWhinnie, D., Jackson, I. (Eds.). (2012). Day Case Surgery (Oxford Specialist Handbooks). Oxford: Oxford University Press.

Smith, I., Cooke, T., Jackson, I., \& Fitzpatrick, R. (2006). Rising to the challenges of achieving day surgery targets. Anaesthesia, 61(12), 11911199. doi:10.1111/j.1365-2044.2006.04875.x.

Sinha, S., Srinivas, G., Montgomery, J., \& DeFriend, D. (2007). Outcome of day-case inguinal hernia in elderly patients: how safe is it?. Hernia, 2007, 11(3), 253-256. doi:10.1007/ s10029-007-0220-9. 
Szczygieł, N., Rutkowska-Podolska, M., \& Michalski, G. (2014). Information and Communication Technologies in Healthcare: Still Innovation or Reality? Innovative and Entrepreneurial Value - creating Approach in Healthcare Management. In 5th Central European Conference in Regional Science CERS (1020-1029).

Šimrová, J., Barták, M., Vojtíšek, R., \& Rogalewicz, V. (2014). The costs and reimbursements for lung cancer treatment among selected health care providers in the Czech Republic. E\&M Ekonomie a Management, 17(3), 74-86. doi:10.15240/ tul/001/2014-3-007.

Škampová, V., Rogalewicz, V., Čeledová, L., \& Čevela, R. (2014). Ambulatory geriatrics in the Czech Republic: A survey of geriatricians' opinions. Kontakt, 16(2), e119-e131. doi:10.1016/j.kontakt.2014.04.002.

Škerjanc, A., \& Fikfak, M.D. (2015). Sickness Presence and Stressful Life Events of Health Care Workers. Cent Eur J Public Health, 23(3), 240-243.

Šoltés, V., \& Gavurová, B. (2014a). The Functionality Comparison of the Health Care Systems by the Analytical Hierarchy Process Method. E\&M Ekonomie a Management, 17(3), 100-117. doi:10.15240/tul/001/2014-3-009.

Šoltés, V., \& Gavurová, B. (2014b). The possibilities of day surgery system development within the health policy in Slovakia. Health Economics Review, 35(4), 1-12. doi:10.1186/ s13561-014-0035-1.

Šoltés, M., \& Gavurová, B. (2014). Identification of the Functionality Level of Day Surgery in Slovakia. Ekonomický časopis, 62(10), 1031-1051.
Toftgaard, C., \& Parmentier, G. (2006). International terminology in ambulatory surgery and its worldwide practice. In P. Lemos, P. Jarrett, B. Philip (Eds.), Day Surgery Development and Practice (35-59). London, UK: International Association for Ambulatory Surgery (IAAS).

Twersky, R.S., \& Philip, B.K. (2008). Handbook of Ambulatory Anesthesia. Springer Science + Business Media.

Vidová, E. (2012). Slovenská asociácia jednodňovej chirurgie. Retrieved July 12, 2012, from http://www.sajch.sk/.

Vidová, E. (2009, February 15). Jednodňová chirurgia má stále malé zastúpenie. primar.sme. sk. Retrieved July 12, 2014, from http://primar. sme.sk/c/4309535/jednodnova-chirurgia-mastale-male-zastupenie.html\#ixzz22nGsswhl.

Wasowicz - Kemps, D.K. (2008). Trends in day surgery in the Netherlands (Thesis). Enschede: University of Utrecht.

Zavadil, M., Rogalewicz, V., \& Kotlanova, S. (2015). Development of Hospital-Based Hta Unit Processes In The Czech Hospital Environment. Value in Health, 18(7), A570. doi:10.1016/j.jval.2015.09.1879.

Zelený, T., \& Bencko, V. (2015). Healthcare System Financing and Profits: All That Glitters is Not Gold. Cent Eur J Public Health, 23(1), 3-7.

Assoc. Prof. Beata Gavurova, PhD. MBA Technical University of Košice Faculty of Economics beata.gavurova@tuke.sk

Assoc. Prof. MD. Marek Soltes, PhD. University of Pavol Jozef Šafárik in Košice 1st Department of Surgery marek.soltes@upjs.sk 


\section{Appendix. 1: \\ Structure of pediatric day surgery for the period 2009-2013 by regions and specialties}
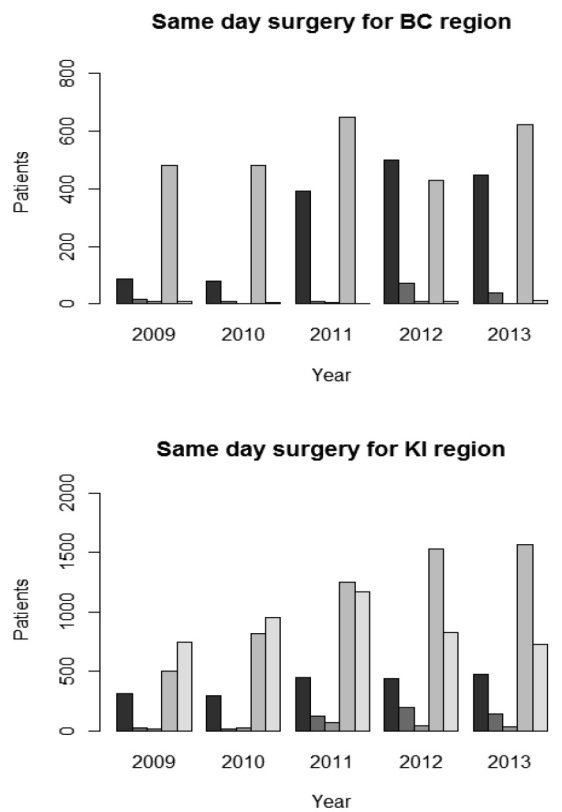

Same day surgery for PV region

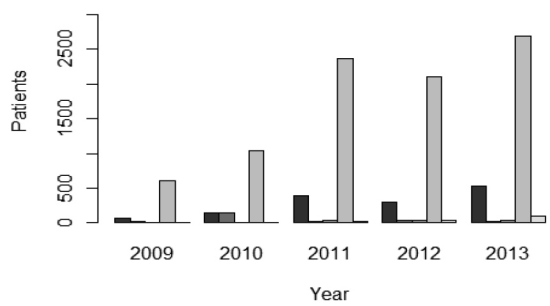

Same day surgery for TC region

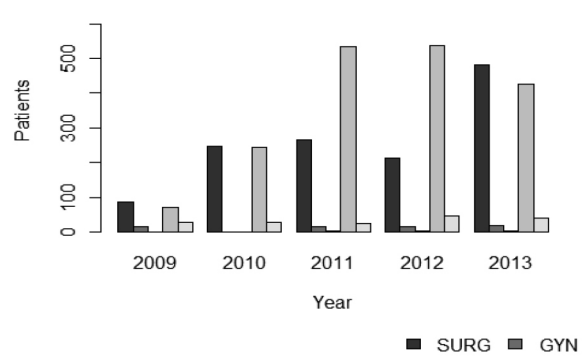

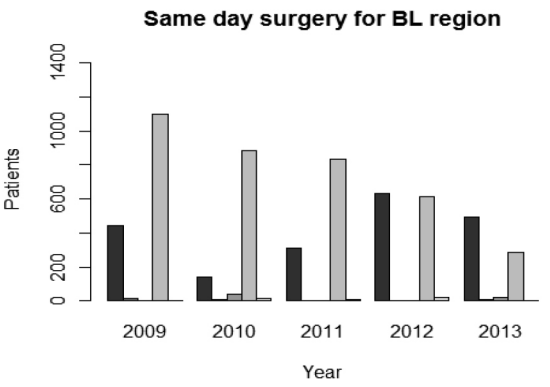

Same day surgery for NI region

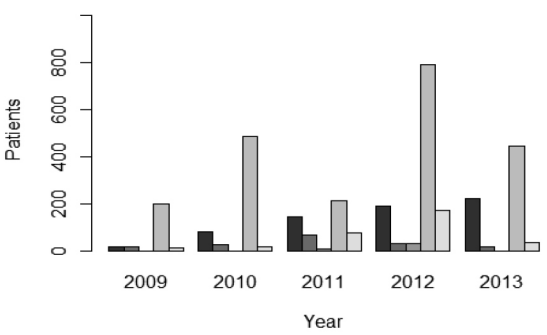

Same day surgery for TA region

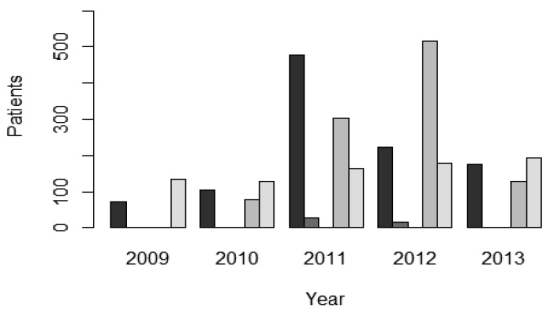

Same day surgery for $\mathrm{ZI}$ region

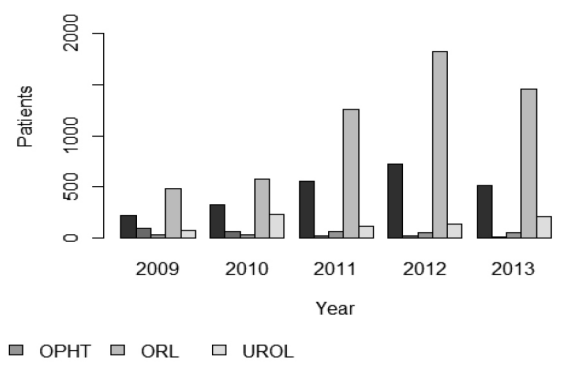



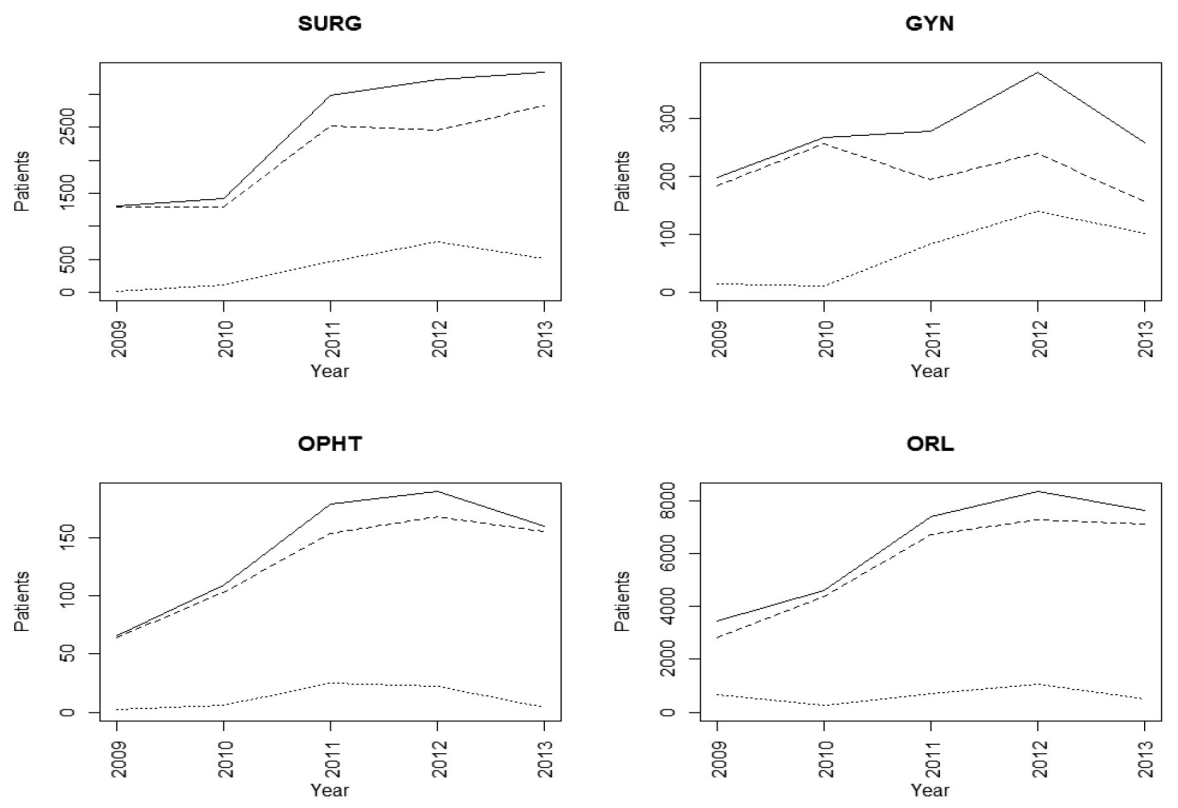

UROL

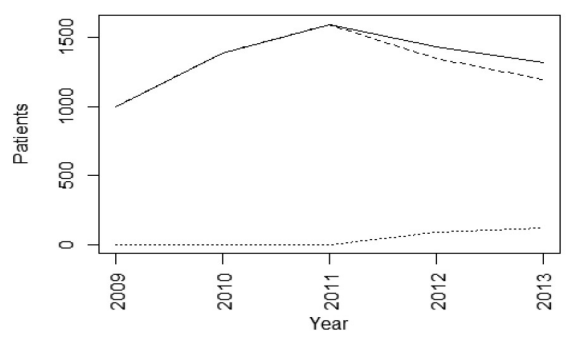

Same day surgery per specialization

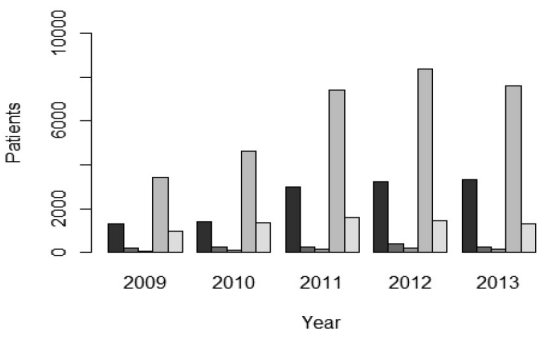

Hospitalized per specialization

Nonhospitalized per specialization
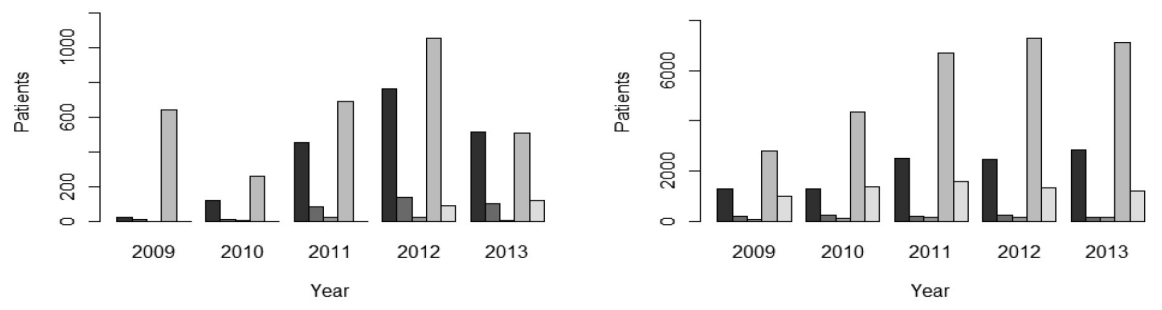

a SURG $\square$ GYN $\square$ OPHT $\square$ ORL $\square$ UROL 


\section{Abstract}

\section{SYSTEM OF DAY SURGERY IN SLOVAKIA: ANALYSIS OF PEDIATRIC DAY SURGERY DISCREPANCIES IN THE REGIONS AND THEIR IMPORTANCE IN STRATEGY OF ITS DEVELOPMENT}

\section{Beata Gavurova, Marek Soltes}

In the recent years in Slovakia occurred some negative changes in settings of the health system which deflected steady relationships in the system and significantly changed the motivation of their participants. It deepened the inefficiency use of healthcare resources. In the foreground of urgent problems is the unresolved issue of ensuring health policy objectives, the availability and quality of health care and the financial sustainability of the system. The indebtedness of Slovak hospitals disproportionately increases and in international comparison of results of healthcare is Slovakia gradually moving away from developed countries. One form of increasing the efficiency of the health system is to support the development of day surgery, which in Slovakia in during its 15 years of existence stagnating and reached only a level of $7 \%$. The aim of the study is to analyze the level of implementation of pediatric day surgery in Slovakia, with special focus on possible regional discrepancies, based on the data available from the National Health Information Centre. This topic was chosen due to specificity of pediatric population compared to the adult one. Analysis revealed uneven trends in the number of completed pediatric day surgery procedures and specified regional disparities. Extreme fluctuations in the proportions of day surgery and traditional in-hospital surgical care suggest deliberate misuse of reporting methodology by some healthcare providers (reporting day surgery procedures as in-hospital care) in various regions during the analyzed period. This observation may be caused by the instability of reimbursement system. With respect to the financial issues, the importance of health insurance companies is obvious, as they have the right to set their own payment strategies and are responsible for the contractual relations with the health care providers. To achieve positive progress in the pediatric day surgery in Slovakia, it is necessary to adjust the active health policy in the country in a way that the balance among the quality of health care, costs, efficiency and equality is achieved.

Key Words: System of day surgery, pediatric day surgery, disparities in the development of pediatric day surgery, development barriers in pediatric day surgery, riskiness of pediatric day surgery.

JEL Classification: I13, I15, I18, I19, H51.

DOI: 10.15240/tul/001/2016-1-006 